\title{
THEO SJAFEI INTERVIEW FORUM 10.8.98
}

Q: What's the significance of the formation of the Military Honor Commission in connection with the kidnappings and disappearances?

A: The Military Honor Commission is the institution used in cases involving the military's honor, for example to investigate whether an officer has committed an ethical violation. As for its internal mechanism, the officer under investigation doesn't need to have a second, or witnesses, or a defense lawyer. He also doesn't need to bring in any evidence. What is at question is his honor, because it involves the honor of all other officers. So he is brought before officers senior to him, to resolve any ethical questions. The Commission will have only two alternatives. Either the officer will be able to continue as an officer, or he will not. In other words, the outcome of the Commission's investigation will mean either that he is dishonorably discharged or that he is allowed to continue his career as an officer. The Commission imposes no other sanctions.

Q: So the[se officers] aren't being investigated for criminal offenses?

A: No, the Commission has no authority to handle criminal cases. Such cases are settled by the courts, not the Commission. The reason is that it is quite possible for someone to be regarded as having committed a crime, but in his capacity as an officer he has simply carried out orders. In such an eventuality, he can be haled before a court, but will not be discharged from military service. So the task of the Commission is merely to investigate whether his actions were carried out in accordance with his military duties. In other words, whether or not his mission was carried out in accord with military ethics. If not, then he will be discharged from service.

Q: These Kopassus people are accused of kidnappings, but they claim they were merely carrying out orders from their superiors. In that case, can they blamed from the point of military ethics?

A: If they acted without the knowledge of their superiors, and simply on their own account, or such and such officer misused the power given him by the state to vent his personal emotions, then he is clearly blameworthy.

Q: But isn't it true that Prabowo says he reported everything to his superior, the Commander of the Armed Forces? 
128 Interview

A: If that is true, then he was simply acting as an officer carrying out a mission. And those who carry out a mission in their capacity as officers may not be dishonorably discharged.

Q: But in this case, Prabowo's superior, General Feisal Tanjung, claims that he never ordered Prabowo to carry out kidnappings.

A: That won't wash. If a subordinate reports to his commander, and it turns out that the commander does nothing to stop him, it means that he [tacitly] permits his subordinate to carry out that mission.

All the more so in a case like this, where the sequestering of the people who were kidnapped lasted for months, yet the commander, after receiving the subordinate's report, did nothing, this is clearly a sign [English]: what was done was permitted. Another example might be a case where a platoon commander reports to his battalion commander that his unit is off in a remote area and is planning to seize a hilltop. If the commander doesn't tell his subordinate not to proceed, he is effectively approving the platoon commander's actions.

Q: Munir of Kontras has stated that resolving this matter via the Commission is a mistake. The officers charged should first be court-martialled, and only then brought before the Commission. What is your view?

A: He's wrong. The Commission's function is simply an investigation of an officer's ethics. They can easily conclude that the officer has committed no criminal offense, and yet his behavior has been incompatible with the honorcode of an officer. In other words, such cases don't always have to be processed through a court-martial.

Q: Do you think it's enough for Prabowo's case to be settled by the Commission, or should he be court-martialled?

A: If it is a matter of a criminal offense, then he has to be court-martialled. The principle, however, is that the Commission cannot decide in criminal cases. The Commission would be very wrong if it did so, since this is clearly not its mission. Its mission is simply to deal with matters concerning the honor of an ABRI officer, not criminal offenses.

Q: Should Feisal Tanjung also be investigated?

A: If the investigation proves that Prabowo reported to him, but he did nothing or just kept quiet, then, yes, Feisal Tanjung should be questioned. The problem is only who would sit on the commission in his case? It would have to be five-star generals! [Laughs].

Q: Were you ever Prabowo's immediate superior?

A: Yes. When I was Commander of Division I, he commanded Battalion 328. In those days he was still a major.

Q: What is your evaluation of Prabowo?

A: Prabowo is an officer with great potential. He thinks far ahead, and is always eager to be way out in front. He also has substantial financial resources and connections with power (kekuasaan). And he always wants to be Number One. In satisfying these ambitions, he sometimes exceeds his authority. Oversteps his assigned 
task. But even if such cases, in my view at least, the one to blame is not Prabowo, but his superior/commander. It is a failure of leadership [English] on the part of his superior officer if he cannot ensure that Prabowo is obedient, loyal, and respectful to his superiors.

Q: Did Prabowo often act this way when he was under your command?

A: Yes. On one or two occasions he wanted his battalion to be something more than just another airborne battalion. He wanted it to be a free fall man [English] battalion. But because this wasn't the mission or the assignment of that battalion, I put a stop to it. He really does think far ahead, and is very ambitious. He made the proposal to me in my capacity as Division Commander. When it came to my attention, I said to him: "This isn't your mission, this isn't your assignment, and it isn't within your authority. The authority in this case is over there [di sana], not in this unit [of yours]." In the end, he obeyed.

Q: Did he ever overstep his authority?

A: Never so long as I was his commanding officer. In handling Prabowo, a great deal depends on the character of his commanding officer. His commanding officer or superiors must be men with clear and firm leadership ability.

Q: Did you ever punish or bawl out Prabowo?

A: Yes. We once held a football competition. Prabowo's battalion was beaten by Battalion 303 from Cikajang. The match took place at Battalion 328's headquarters. As the host team, Battalion 328 felt they were fully prepared and they expected to win. But that's not the way it turned out. Now Prabowo, the battalion commander, is not a man who takes losing easily. So he messed with a car belonging to Battalion 303 [so it couldn't run]. So I summoned the whole Battalion, including Prabowo. I told them that "sport is training for defeat as well as victory. Our nation takes part in the Southeast Asian Games and the Asian Games to learn how to lose as well as to how to win. We have to be able to accept defeat, as a nation, in an international event [English]. Even more so for us soldiers. We have to be able to accept defeat. Otherwise, we can easily destroy the whole population in an area where operations are being carried out.

But that won't happen if we learn humility. There are also people who can not accept victory [in proportion], so that they use it for self-glorification." That was how I chewed out the whole of Battalion 328, including its commander. It was a very tough chewing out I gave them. After that, they never did it again. And from that day on up till now, my relations with Prabowo have always been good.

\section{A: So his commander has to be strict?}

Q: Yes. In fact, out there I once said: "So long as I am Division Commander here, no soldier may carry out orders from anyone other than me. If anyone tries to give orders outside the chain of command, I'll shoot." I made this clear from the very beginning. So probably if people say I'm tough, there's some truth in it [laughs]. During my tour of duty there, there were no stupid complaints, for example bitching by one battalion commander about another. There was no jealousy. But in my view, this depends on leadership. That is why, if it turns out that Prabowo is judged to have done what people accuse him of, I see it more a failure of Prabowo's commanding officers than of 
130 Interview

Prabowo himself. I can't accept the statement of Feisal Tanjung that he had no idea what was going on. Even worse, he even said he couldn't [i.e. wasn't allowed to] enter Kopassus headquarters. This is rubbish. If the ABRI Commander is like that, what's the world coming to?

Q: So you mean that Prabowo can be controlled if his superiors are tough?

A: Well, it so happens, that I could control him. But it's not just only me. Plenty of his commanders could handle him. Yunus Yosfiah was once Prabowo's commander, and he could. Wismoyo Arismunandar also could. Hendropriyono too. All of them could control Prabowo.

\section{Q: So who couldn't?}

A: [Laughs]. Well, General Hartono even went so far as to use Prabowo to get closer to the center of power. Because he looked at Prabowo as Pak Harto's son-in-law, he thought he could use him.

Q: What is your estimation of the course of Prabowo's career? Is it true that he was given special treatment?

A: Yes, I saw Prabowo getting special treatment. Particularly and excessively at the hands of ABRI Commander Feisal Tanjung and Army Chief of Staff Hartono. Prabowo would never have gotten into the present mess if he had been properly trained and developed [dibina] by the Army Chief of Staff. But even before that he got special treatment. Normally, after serving as battalion commander, he should have become a Kodim [Military District] commander. Given his temperament, if he' $\mathrm{d}$ become a Kodim commander, it's quite possible he would have got into conflicts with students, or workers, or with businessmen. This would have been a learning experience for him, so he wouldn't do the same thing when he moved to higher positions. But the fact is he never became a Kodim commander, never became a Korem [Military Sub-region] commander, Kodam [Regional Command] chief of staff, or Regional Commander. He never moved up the military ladder step by step like ordinary officers. But if he had gone up through them all, one by one, his temperament would have brought about clashes at the lower levels. In that way, he would have learned from the People [rakyat]. All of us learn something with every step up the career ladder. The higher we go, therefore, the more prudent and wise we get.

Q: Was the special treatment the result of orders from Pak Harto?

A: I don't know. At least while I was his commanding officer, there were no such orders. I regarded him as one of my boys [anak buah]. Not an anak buah of Suharto who was then President. So, even though in those days there were some people who whispered in my ear, I regarded these whispers as nonsense.

Q: Still, it does look as if Prabowo's rapid rise was significantly helped by his being Pak Harto's son-in-law.

A: That's right, it looks that way if you compare him with his classmates. He was given an easier ride, in that he didn't have to go up rung by rung as is normal in ABRI. And he also never entered what you could call the "staff world," where his ideas would have had to be formed into clear concepts for presentation to his commander, and which could be rejected by his commander. 
Q: Subagyo, the Army Chief of Staff and Chairman of the Military Honor Commission, is a former bodyguard of Pak Harto. Can the Commission be objective?

A: I certainly hope it can be objective, courageous, and honest. The thing is, on paper, Subagyo was once Prabowo's commanding officer in Kopassus. When Subagyo was Commander-General of Kopassus, Prabowo was his deputy. Yet, operationally, in the field, it was very obvious that it was Prabowo who controlled/ran Kopassus,. not Bagyo. Bagyo was just a symbol [simbol] at that time. Everyone recognized this. So I can't blame people . . . . After all, it's true that there are suspicions about Subagyo's objectivity on the Commission. But then again, who are the four-star generals still on active duty aside from Pak Wiranto and Pak Bagyo? Prabowo has three stars, so it's a problem isn't it? My guess is that Subagyo was picked for the job [of chairman] because Pak Wiranto had no other choice.

Q: Agum Gumelar also was once Prabowo's immediate commanding officer. Can he too be objective?

A: Agum Gumelar has been great with Prabowo, meaning, he really exercised good leadership towards him. He situated himself this way: I am Prabowo's superior officer, and I have to control him. Very fine. Seen through military lenses, from the angle of discipline and mission, Agum Gumelar has handled Prabowo much better ....

If we use military lenses to view Subagyo vis-à-vis Prabowo, what we'll see is that when Subagyo was Commander-General of Kopassus, he was just a symbol of Kopassus, while the person who controlled it was Prabowo.

Q: When you look at the Commission's membership, do you think it's possible for them to give a really objective evaluation of Prabowo?

A: Well, we had a commission like this at the time of the Santa Cruz affair, and I don't see a single person on the present Commission who had any experience there [?? Unclear where he means someone who had experience in East Timor, or who sat on the earlier Commission. which, after all, was created six years earlier]. Usually, if a lieutenant-general is brought before the Commission, its leader is a full general. One is enough. In Prabowo's case, it should be a full general on top of a number of lieutenantgenerals. All the interrogators are lieutenant-generals. But in the case of Muchdi, since Muchdi is a major-general, then the interrogators should also be major-generals. [The rule thus is that] the interrogators should have the same rank as the interrogated. The idea here is to make the officer under interrogation psychologically aware that "your feelings and ours are the same. The military honor that you bear [on your shoulders] and the military honor we bear are the same." 
